\title{
Concentrations and stable carbon isotope compositions of oxalic acid and related SOA in Beijing before, during, and after the 2014 APEC
}

\author{
Jiayuan Wang ${ }^{1,3}$, Gehui Wang ${ }^{1,2,3,4}$, Jian Gao ${ }^{5,6}$, Han Wang ${ }^{5,6}$, Yanqin Ren ${ }^{1,3}$, Jianjun $\mathbf{L i}^{1}$, Bianhong Zhou ${ }^{1}$, \\ Can Wu ${ }^{1,3}$, Lu Zhang ${ }^{1,3}$, Shulan Wang ${ }^{5,6}$, and Fahe Chai ${ }^{5,6}$ \\ ${ }^{1}$ State Key Laboratory of Loess and Quaternary Geology, Key Lab of Aerosol Chemistry and Physics, \\ Institute of Earth Environment, Chinese Academy of Sciences, Xi' an 710061, China \\ ${ }^{2}$ School of Human Settlements and Civil Engineering, Xi' an Jiaotong University, Xi' an 710079, China \\ ${ }^{3}$ University of Chinese Academy of Sciences, Beijing 100049, China \\ ${ }^{4}$ Center for Excellence in Regional Atmospheric Environment, Institute of Urban Environment, \\ Chinese Academy of Sciences, Xiamen 361021, China \\ ${ }^{5}$ State Key Laboratory of Environmental Criteria and Risk Assessment, Chinese Research Academy of \\ Environmental Sciences, Beijing 100084, China \\ ${ }^{6}$ Collaborative Innovation Center of Atmospheric Environment and Equipment Technology, Nanjing 210000, China \\ Correspondence to: Gehui Wang (wanggh@ieecas.cn) and Jian Gao (gaojian@craes.org.cn)
}

Received: 22 July 2016 - Published in Atmos. Chem. Phys. Discuss.: 22 August 2016

Revised: 29 December 2016 - Accepted: 3 January 2017 - Published: 23 January 2017

\begin{abstract}
To ensure good air quality for the 2014 AsiaPacific Economic Cooperation (APEC) summit, stringent emission controls were implemented in Beijing and its surrounding regions, leading to a significant reduction in $\mathrm{PM}_{2.5}$ loadings. To investigate the impact of the emission controls on aerosol chemistry, high-volume $\mathrm{PM}_{2.5}$ samples were collected in Beijing from 8 October to 24 November 2014 and determined for secondary inorganic aerosols (SIA, i.e., $\mathrm{SO}_{4}^{2-}, \mathrm{NO}_{3}^{-}$, and $\mathrm{NH}_{4}^{+}$), dicarboxylic acids, keto-carboxylic acid, and $\alpha$-dicarbonyls, as well as stable carbon isotope composition of oxalic acid $\left(\mathrm{C}_{2}\right)$. Our results showed that SIA, $\mathrm{C}_{2}$, and related secondary organic aerosols in $\mathrm{PM}_{2.5}$ during APEC were 2-4 times lower than those before APEC, which is firstly ascribed to the strict emission control measures and secondly attributed to the relatively colder and drier conditions during the event that are unfavorable for secondary aerosol production.

$\mathrm{C}_{2}$ in the polluted air masses, which mostly occurred before APEC, are abundant and enriched in ${ }^{13} \mathrm{C}$. On the contrary, $\mathrm{C}_{2}$ in the clean air masses, which mostly occurred during APEC, is much less abundant but still enriched in ${ }^{13} \mathrm{C}$. In the mixed type of clean and polluted air masses, which mostly occurred after APEC, $\mathrm{C}_{2}$ is lower than that before
\end{abstract}

APEC but higher than that during APEC and enriched in lighter ${ }^{12} \mathrm{C}$. A comparison on chemical composition of fine particles and $\delta^{13} \mathrm{C}$ values of $\mathrm{C}_{2}$ in two events that are characterized by high loadings of $\mathrm{PM}_{2.5}$ further showed that after APEC SIA and the total detected organic compounds (TDOC) are much less abundant and fine aerosols are enriched with primary organics and relatively fresh, compared with those before APEC.

\section{Introduction}

Atmospheric aerosols profoundly impact the global climate directly by scattering and absorbing solar radiation and indirectly by affecting cloud formation and distribution via acting as cloud condensation nuclei $(\mathrm{CCN})$ and ice nuclei (IN). Moreover, atmospheric aerosols exert negative effects on human health because of their toxicity. Due to fast urbanization and industrialization, high levels of atmospheric fine particle $\left(\mathrm{PM}_{2.5}\right)$ pollution have been a persistent problem in many cities of China since the 1990s (van Donkelaar et al., 2010). As the capital of China and one of the largest megacities in the world, Beijing has suffered from frequent severe 
haze pollution, especially in winter, affecting more than 21 million people by the end of 2014 (Beijing Municipal Bureau of Statistics, 2015) and causing billions in economic losses (Mu and Zhang, 2013). To improve the air quality, the Beijing government has made many efforts to reduce the pollutant emissions (i.e., $\mathrm{SO}_{2}, \mathrm{NO}_{x}$, dust, and volatile organic compounds (VOCs)) from a variety of sources. The 2014 Asia-Pacific Economic Cooperation (APEC) summit was hosted in Beijing from 5 to 11 November. To ensure good air quality for the summit, a joint strict emission control program was conducted from 3 November 2014 in Beijing and its neighboring provinces including Inner Mongolia, Shanxi, Hebei, and Shandong provinces. During this period thousands of factories and power plants with high emissions were shut down and/or halted, all the construction activities were stopped, and the numbers of on-road vehicles were reduced. These strict emission controls resulted in the air quality of Beijing during the APEC period being significantly improved, leading to a decrease in $\mathrm{PM}_{2.5}$ concentration by $59.2 \%$ and an increase in visibility by $70.2 \%$ in Beijing during the summit compared with those before the APEC (Tang et al., 2015; Z. Wang et al., 2015) and a term of "APEC blue" being created to refer to the good air quality. Such strong artificial intervening not only reduced $\mathrm{PM}_{2.5}$ and its precursors' loadings in Beijing and its surrounding areas but also affected the composition and formation mechanisms of the fine particles (Sun et al., 2016).

A number of field measurements have shown that particle compositions in Beijing during wintertime haze periods are dominated by secondary aerosols (Guo et al., 2014; Huang et al., 2014; Xu et al., 2015). Rapid accumulation of particle mass in Beijing during the haze formation process is often accompanied by continuous particle size growth (Guo et al., 2014; Zhang et al., 2015), which is in part due to the coating of secondary organic aerosols (SOA) on pre-existing particles (Li et al., 2010). Several studies have found that SOA production during the 2014 Beijing APEC periods significantly reduced and ascribed this reduction to the efficient regional emission control (Sun et al., 2016; Xu et al., 2015). However, up to now information on the SOA decrease on a molecular level has not been reported.

Dicarboxylic acids are the major class of SOA species in the atmosphere and ubiquitously found from the ground surface to the free troposphere (Fu et al., 2008; Myriokefalitakis et al., 2011; Sorooshian et al., 2007; Sullivan and Prather, 2007). Previous studies have suggested that organic acids including dicarboxylic acids could take part in atmospheric particle nucleation (Zhang et al., 2004; Zhao et al., 2009) and growth processes (Zhang et al., 2012). Furthermore, organic acids may play a central role in the aging of black carbon particles (Xue et al., 2009; Ma et al., 2013), enhancing their roles in air pollution accumulation, and direct radiative forcing (Peng et al., 2016). In the current work we measured molecular distributions of dicarboxylic acids, keto-carboxylic acids and $\alpha$-dicarbonyls and stable carbon isotope composition of oxalic acid in $\mathrm{PM}_{2.5}$ aerosols collected in Beijing before, during, and after the APEC event in order to explore the impact of the APEC emission control on SOA in Beijing. We first investigated the changes in concentration and composition of dicarboxylic acids and related compounds during the three periods, then recognized the difference in stable carbon isotope composition of oxalic acid in different air masses in Beijing during the APEC campaign. Finally we compared the differences in chemical compositions of $\mathrm{PM}_{2.5}$ during two heaviest pollution episodes.

\section{Experimental section}

\subsection{Sample collection}

$\mathrm{PM}_{2.5}$ samples were collected by using a high-volume sampler (TISCH, USA) from 8 October to 24 November 2014 on the rooftop of a three-storey building located on the campus of the China Research Academy of Environmental Sciences, which is situated in the north part of Beijing and close to the fifth ring road. All the $\mathrm{PM}_{2.5}$ samples were collected onto pre-baked $\left(450{ }^{\circ} \mathrm{C}\right.$ for $8 \mathrm{~h}$ ) quartz fiber filters (Whatman 41 , USA). The duration of each sample collection is $23 \mathrm{~h}$ from 08:00 LT of the previous day to 07:00 LT of the next day. Field blanks were also collected before and after the campaign by mounting a pre-baked filter onto the sampler for 15 min without pumping air. After collection, all the filter samplers were individually sealed in aluminum foil bags and stored in a freezer $\left(-18^{\circ} \mathrm{C}\right)$ prior to analysis. Daily values of $\mathrm{SO}_{2}, \mathrm{NO}_{x}$, and meteorological parameters were cited from the website of Beijing Environmental Protection Agency.

\subsection{Sample analysis}

\subsubsection{Elemental carbon (EC), organic carbon (OC), water-soluble organic carbon (WSOC), inorganic ions, aerosol liquid water content (ALWC) and aerosol acidity}

Detailed methods for the analysis of EC, OC, WSOC, and inorganic ions in aerosols were reported elsewhere (Wang et al., 2010). Briefly, EC and OC in the $\mathrm{PM}_{2.5}$ samples were determined by using DRI Model 2001 Carbon analyzer following the Interagency Monitoring of Protected Visual Environments (IMPROVE) thermal/optical reflectance (TOR) protocol (Chow et al., 2007). WSOC and inorganic ions in the samples were extracted with Milli-Q pure water and measured by using a Shimadzu TOC-L CPH analyzer and Dionex-600 ion chromatography, respectively (Wang et al., 2010). In the current work, aerosol liquid water content (ALWC) and acidity (i.e., liquid $\mathrm{H}^{+}$concentrations, $\left.\left[\mathrm{H}^{+}\right]\right)$of the samples were calculated by using ISORROPIA-II model, which treated the $\mathrm{Na}^{+}-\mathrm{NH}_{4}^{+}-\mathrm{K}^{+}-\mathrm{Ca}^{2+}-\mathrm{Mg}^{2+}-\mathrm{Cl}^{-}-\mathrm{NO}_{3}^{-}-\mathrm{SO}_{4}^{2-}$ system (Hennigan et al., 2015; Weber et al., 2016). 


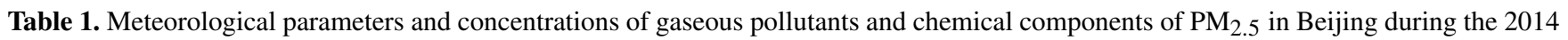
APEC campaign.

\begin{tabular}{|c|c|c|c|c|}
\hline & $\begin{array}{l}\text { Whole period } \\
\qquad(N=48)\end{array}$ & $\begin{array}{r}\text { Before APEC } \\
(08 / 10-02 / 11) \\
(N=26)\end{array}$ & $\begin{array}{r}\text { During APEC } \\
(03 / 11-12 / 11) \\
(N=10)\end{array}$ & $\begin{array}{r}\text { After APEC } \\
(13 / 11-14 / 11) \\
(N=12)\end{array}$ \\
\hline \multicolumn{5}{|c|}{ I. Meteorological parameters } \\
\hline Temperature, ${ }^{\circ} \mathrm{C}$ & $9.5 \pm 4.3(3.0-18)$ & $13 \pm 2.6(9.0-18)$ & $7.0 \pm 1.7(4.0-10)$ & $4.3 \pm 1.3(3.0-7.0)$ \\
\hline Relative humidity, \% & $56 \pm 19(17-88)$ & $62 \pm 19(22-88)$ & $47 \pm 14(17-65)$ & $51 \pm 16(29-80)$ \\
\hline Visibility, km & $8.8 \pm 6.8(1.0-28)$ & $7.3 \pm 6.6(1.0-24)$ & $13 \pm 7.7(6.0-28)$ & $7.2 \pm 4.2(2.0-15)$ \\
\hline Wind speed, $\mathrm{km} \mathrm{h}^{-1}$ & $8.0 \pm 4.9(3.0-26)$ & $7.6 \pm 4.8(3.0-26)$ & $9.4 \pm 6.6(3.0-26)$ & $7.8 \pm 2.9(3.0-13)$ \\
\hline \multicolumn{5}{|c|}{ II. Gaseous pollutants, $\mu \mathrm{g} \mathrm{m}^{-3}$} \\
\hline $\mathrm{O}_{3}$ & $48 \pm 23(6.0-115)$ & $55 \pm 24(9.0-115)$ & $52 \pm 13(25-69)$ & $29 \pm 18(6.0-60)$ \\
\hline $\mathrm{SO}_{2}$ & $12 \pm 8.5(2.0-43)$ & $8.8 \pm 4.6(2.0-19)$ & $7.6 \pm 3.9(2.0-15)$ & $23 \pm 8.8(13-43)$ \\
\hline $\mathrm{NO}_{2}$ & $68 \pm 29(10-135)$ & $71 \pm 27(22-118)$ & $45 \pm 18(10-69)$ & $78 \pm 29(45-135)$ \\
\hline $\mathrm{CO}$ & $1360 \pm 730(220-3320)$ & $1370 \pm 700(250-2460)$ & $960 \pm 410(220-1420)$ & $1720 \pm 830(740-3320)$ \\
\hline \multicolumn{5}{|c|}{ III. Major components of $\mathrm{PM}_{2.5}, \mu \mathrm{g} \mathrm{m}^{-3}$} \\
\hline $\mathrm{PM}_{2.5}$ & $157 \pm 110(16-408)$ & $178 \pm 122(16-408)$ & $98 \pm 46(28-183)$ & $161 \pm 100(36-383)$ \\
\hline $\mathrm{SO}_{4}^{2-}$ & $12 \pm 11.5(1.2-43)$ & $15 \pm 13(1.2-43)$ & $5.3 \pm 2.8(1.8-11)$ & $11 \pm 10(2.9-34)$ \\
\hline $\mathrm{NO}_{3}^{-}$ & $21 \pm 22(0.32-88)$ & $28 \pm 26(0.32-88)$ & $10 \pm 8.1(1.2-26)$ & $15 \pm 13(2.9-46)$ \\
\hline $\mathrm{NH}_{4}^{+3}$ & $7.3 \pm 7.2(0.2-28)$ & $9.0 \pm 8.0(0.2-28)$ & $3.1 \pm 2.6(0.2-8.6)$ & $6.9 \pm 6.4(1.0-22)$ \\
\hline $\mathrm{OC}^{\mathrm{a}}$ & $28 \pm 18(5.7-78)$ & $26 \pm 16(6.0-67)$ & $19 \pm 7.6(5.7-29)$ & $39 \pm 23(9.7-78)$ \\
\hline $\mathrm{EC}^{\mathrm{a}}$ & $8.8 \pm 5.4(1.4-25)$ & $8.6 \pm 4.6(1.4-18)$ & $6.0 \pm 2.7(1.5-9.6)$ & $12 \pm 7.0(2.1-25)$ \\
\hline WSOC $^{\mathrm{b}}$ & $10 \pm 6.0(2.4-32)$ & $11 \pm 4.6(3.1-32)$ & $6.4 \pm 2.6(2.4-11)$ & $11 \pm 6.1(4.5-24)$ \\
\hline $\mathrm{ALWC}^{\mathrm{c}}$ & $40 \pm 62(0-299)$ & $58 \pm 75(0-299)$ & $6.3 \pm 5.5(0-19)$ & $28 \pm 41(0.4-136)$ \\
\hline$\left[\mathrm{H}^{+}\right]^{\mathrm{d}}$ & $0.083 \pm 0.14(0-0.56)$ & $0.13 \pm 0.17(0-0.56)$ & $0.026 \pm 0.025(0-0.072)$ & $0.033 \pm 0.067(0-0.20)$ \\
\hline \multicolumn{5}{|c|}{ IV. Mass ratios of major components of $\mathrm{PM}_{2.5}$} \\
\hline $\mathrm{NO}_{3}^{-} / \mathrm{SO}_{4}^{2-}$ & $1.6 \pm 0.8(0.3-4.3)$ & $1.7 \pm 0.9(0.3-4.3)$ & $1.6 \pm 0.7(0.5-2.4)$ & $1.4 \pm 0.4(0.8-2.2)$ \\
\hline $\mathrm{OC}^{3} / \mathrm{EC}^{4}$ & $3.3 \pm 0.6(2.2-4.7)$ & $3.2 \pm 0.7(2.2-4.5)$ & $3.3 \pm 0.6(2.0-4.3)$ & $3.4 \pm 0.5(2.7-4.7)$ \\
\hline WSOC / OC & $0.39 \pm 0.15(0.10-0.71)$ & $0.42 \pm 0.13(0.13-0.71)$ & $0.38 \pm 0.16(0.16-0.65)$ & $0.35 \pm 0.17(0.10-0.63)$ \\
\hline
\end{tabular}

${ }^{a}$ Organic carbon (OC) and elemental carbon (EC). ${ }^{b}$ Water-soluble organic carbon (WSOC). ${ }^{c}$ Aerosol liquid water content (ALWC). ${ }^{\mathrm{d}}$ Hydrogen ion concentration ([H $\left.\left.{ }^{+}\right]\right)$.

\subsubsection{Dicarboxylic acids, keto-carboxylic acids and $\alpha$-dicarbonyls}

The method of analyzing $\mathrm{PM}_{2.5}$ samples for dicarboxylic acids, ketocarboxylic acids and $\alpha$-dicarbonyl has been reported elsewhere (Wang et al., 2002, 2012; Meng et al., 2014; Cheng et al., 2015). Briefly, one eighth of the filter was extracted with Milli-Q water, concentrated to near dryness, and reacted with $14 \% \mathrm{BF}_{3} /$ butanol at $100^{\circ} \mathrm{C}$ for $1 \mathrm{~h}$ to convert the aldehyde group into dibutoxy acetal and the carboxyl group into butyl ester. Target compounds in the derivatized samples were identified by gas chromotography-mass spectrometry (GC-MS) and quantified by a gas chromotographyflame ionization detector (GC-FID) (Agilent GC7890A).

\subsection{Stable carbon isotope composition of oxalic acid $\left(\mathbf{C}_{2}\right)$}

Stable carbon isotope composition $\left(\delta^{13} \mathrm{C}\right)$ of $\mathrm{C}_{2}$ was measured using the method developed by Kawamura and Watanabe (2004). Briefly, $\delta^{13} \mathrm{C}$ values of the derivatized samples above were determined by gas chromatography-isotope ratio mass spectrometry (GC-IR-MS; Thermo Fisher, Delta V Advantage). The $\delta^{13} \mathrm{C}$ value of $\mathrm{C}_{2}$ was then calculated from an isotopic mass-balance equation based on the measured $\delta^{13} \mathrm{C}$ of the derivatizations and the derivatizing reagent (1-butanol; Kawamura and Watanabe, 2004). Each sample was measured three times to ensure the difference of the $\delta^{13} \mathrm{C}$ values less than $0.2 \%$, and the isotope data reported here are the averaged value of the triplicate measurements. 
Table 2. Concentrations of dicarboxylic acids and related compounds in $\mathrm{PM}_{2.5}$ in Beijing during the 2014 APEC campaign (ng $\mathrm{m}^{-3}$ ).

\begin{tabular}{|c|c|c|c|c|}
\hline & $\begin{array}{r}\text { Whole period } \\
\qquad(N=48)\end{array}$ & $\begin{array}{r}\text { Before APEC } \\
(08 / 10-02 / 11) \\
(N=26) \\
\end{array}$ & $\begin{array}{r}\text { During APEC } \\
(03 / 11-12 / 11) \\
(N=10) \\
\end{array}$ & $\begin{array}{r}\text { After APEC } \\
(13 / 11-14 / 11) \\
(N=12) \\
\end{array}$ \\
\hline \multicolumn{5}{|c|}{ I. Dicarboxylic acids } \\
\hline Oxalic, $\mathrm{C}_{2}$ & $334 \pm 461(10-2127)$ & $502 \pm 564(10.5-2127)$ & $101 \pm 69(35-251)$ & $166 \pm 157(22-554)$ \\
\hline Malonic, $\mathrm{C}_{3}$ & $31 \pm 42\left(\mathrm{ND}^{\mathrm{a}}-247\right)$ & $45.7 \pm 52.1(1.44-247)$ & $12 \pm 8.0(3.4-22.8)$ & $16 \pm 10.9(\mathrm{ND}-36)$ \\
\hline Succinic, $\mathrm{C}_{4}$ & $74 \pm 118(3.0-722)$ & $111 \pm 150(3.0-722)$ & $24 \pm 14(7.1-42)$ & $36 \pm 26(4.9-90)$ \\
\hline Glutaric, $\mathrm{C}_{5}$ & $8.7 \pm 12(\mathrm{ND}-68)$ & $13 \pm 15(\mathrm{ND}-68.1)$ & $2.9 \pm 2.24(0.9-5.8)$ & $4.9 \pm 4.2(\mathrm{ND}-13)$ \\
\hline Adipic, $\mathrm{C}_{6}$ & $13 \pm 14(0.9-83)$ & $17 \pm 18(1.9-83)$ & $5.9 \pm 3.8(2.1-14)$ & $9.9 \pm 7.1(2.0-23)$ \\
\hline Pimelic, $\mathrm{C}_{7}$ & $2.1 \pm 3.8(\mathrm{ND}-27)$ & $2.6 \pm 5.1(\mathrm{ND}-27)$ & $1.1 \pm 0.7(0.2-2.3)$ & $2.0 \pm 1.1(0.9-4.4)$ \\
\hline Suberic, $\mathrm{C}_{8}$ & $10 \pm 11(\mathrm{ND}-66)$ & $12 \pm 13(\mathrm{ND}-66)$ & $7.6 \pm 5.0(1.3-16)$ & $8.7 \pm 6.0(2.0-21)$ \\
\hline Azelaic, $\mathrm{C}_{9}$ & $5.0 \pm 4.9(0.5-21)$ & $6.4 \pm 5.7(0.6-21)$ & $1.7 \pm 0.9(0.5-3.2)$ & $4.6 \pm 3.3(1.3-13)$ \\
\hline Sebacic, $\mathrm{C}_{10}$ & $7.7 \pm 7.4(\mathrm{ND}-34)$ & $9.4 \pm 8.8(\mathrm{ND}-34)$ & $4.2 \pm 3.6(0.5-11)$ & $6.8 \pm 4.9(1.4-16)$ \\
\hline Undecanedioic, $\mathrm{C}_{11}$ & $11 \pm 13(\mathrm{ND}-77)$ & $14 \pm 16(\mathrm{ND}-77)$ & $3.3 \pm 2.5(\mathrm{ND}-7.5)$ & $9.4 \pm 6.4(0.8-23)$ \\
\hline Methylsuccinic, $\mathrm{iC}_{5}$ & $13 \pm 16(0.6-79)$ & $18 \pm 19(0.6-79)$ & $4.8 \pm 3.0(1.0-9.2)$ & $8.4 \pm 6.0(2.3-19)$ \\
\hline Methyglutaric, $\mathrm{iC}_{6}$ & $7.5 \pm 10(\mathrm{ND}-36)$ & $11 \pm 12(\mathrm{ND}-36)$ & $0.9 \pm 09(\mathrm{ND}-2.6)$ & $4.6 \pm 5.1(\mathrm{ND}-14)$ \\
\hline Maleic, M & $3.4 \pm 3.9(\mathrm{ND}-15)$ & $4.6 \pm 4.7(\mathrm{ND}-15)$ & $1.4 \pm 0.8(\mathrm{ND}-2.9)$ & $2.4 \pm 2.0(\mathrm{ND}-6.3)$ \\
\hline Fumaric, F & $7.2 \pm 8.8(\mathrm{ND}-64)$ & $10 \pm 11(\mathrm{ND}-64)$ & $2.2 \pm 1.5(\mathrm{ND}-5.4)$ & $4.7 \pm 3.2(1.4-10)$ \\
\hline Phthalic, $\mathrm{Ph}$ & $17 \pm 14(1.5-64)$ & $20 \pm 16(1.5-64)$ & $10 \pm 6.8(2.3-20)$ & $17 \pm 9.0(6.4-31)$ \\
\hline Isophthalic, $\mathrm{iPh}$ & $2.1 \pm 2.5(\mathrm{ND}-10)$ & $2.9 \pm 2.8(\mathrm{ND}-10)$ & $2.0 \pm 2.1(0.2-5.9)$ & $0.5 \pm 0.3(\mathrm{ND}-3.2)$ \\
\hline Terephthalic, $\mathrm{tPh}$ & $46 \pm 35(2.6-133)$ & $50 \pm 35(2.6-123)$ & $28 \pm 19(4.7-59)$ & $53 \pm 40(7.4-133)$ \\
\hline Subtotal & $593 \pm 739(25-3788)$ & $849 \pm 905(25-3788)$ & $214 \pm 135(72-447)$ & $354 \pm 279(85-965)$ \\
\hline \multicolumn{5}{|c|}{ II. Keto-carboxylic acids } \\
\hline Pyruvic, Pyr & $24 \pm 20(1.3-84)$ & $31 \pm 23(2.4-84)$ & $15 \pm 12(1.3-36)$ & $15 \pm 9.3(3.2-33)$ \\
\hline Glyoxylic, $\omega \mathrm{C}_{2}$ & $33 \pm 51(1.2-300)$ & $48 \pm 64(1.2-300)$ & $10 \pm 7.7(2.6-21)$ & $20 \pm 23(2.8-80)$ \\
\hline 7-Oxoheptanoic, $\omega \mathrm{C}_{7}$ & $8.8 \pm 14$ (ND-90) & $13 \pm 17$ (ND-90) & $4.2 \pm 3.6(\mathrm{ND}-13)$ & $4.5 \pm 5.1(\mathrm{ND}-17)$ \\
\hline Subtotal & $66 \pm 81(3.6-474)$ & $92 \pm 99(3.6-474)$ & $30 \pm 22(5.9-66)$ & $40 \pm 35(13-128)$ \\
\hline \multicolumn{5}{|c|}{ III $\alpha$-Dicarbonyls } \\
\hline Glyoxal, Gly & $44 \pm 47(4.2-270)$ & $57 \pm 56(4.2-270)$ & $22 \pm 19(4.9-47)$ & $35 \pm 30(7.3-101)$ \\
\hline Methylglyoxal, mGly & $82 \pm 82(\mathrm{ND}-406)$ & $102 \pm 96(\mathrm{ND}-406)$ & $60 \pm 52(15-139)$ & $58 \pm 51(5.8-144)$ \\
\hline Subtotal & $126 \pm 115(5.3-466)$ & $158 \pm 132(5.3-466)$ & $81.6 \pm 67.4(22-186)$ & $93 \pm 80(14-225)$ \\
\hline TDOC $^{\mathrm{b}}$ & $785 \pm 872(36-4636)$ & $1099 \pm 1104(36-4636)$ & $325 \pm 220(107-664)$ & $487 \pm 387(117-1318)$ \\
\hline
\end{tabular}

${ }^{a}$ ND: not detectable. ${ }^{b}$ TDOC: total detected organic compounds.

\section{Results and discussion}

3.1 Variations in meteorological conditions, gaseous pollutants, and major components of $\mathbf{P M}_{2.5}$ during the Beijing 2014 APEC campaign

Based on the emission control implementation for the APEC, we divided the whole study period into three phases: before APEC (8 October to 2 November), during APEC (3 to 12 November) and after APEC (13 to 24 November). Temporal variations in meteorological parameters and concentrations of gaseous pollutants and major components of $\mathrm{PM}_{2.5}$ during the three phases are shown in Fig. 1 and summarized in Table 1.

Temperature during the sampling campaign showed a continuous decreasing trend with averages of $13 \pm 2.6,7.0 \pm 1.7$, and $4.3 \pm 1.3{ }^{\circ} \mathrm{C}$ before, during, and after APEC, respec- tively, while relative humidity $(\mathrm{RH})$ did not show a clear trend, with mean values of $62 \pm 19,47 \pm 14$, and $51 \pm 16 \%$ during the three periods (Fig. 1a and Table 1). $\mathrm{SO}_{2}$ showed a similar level before and during APEC $\left(8.8 \pm 4.6 \mu \mathrm{g} \mathrm{m}^{-3}\right.$ versus $7.6 \pm 3.9 \mu \mathrm{g} \mathrm{m}^{-3}$; Table 1 and Fig. 1b), but increased dramatically to $23 \pm 8.8 \mathrm{\mu g} \mathrm{m}^{-3}$ after APEC due to domestic coal burning for house heating. $\mathrm{NO}_{2}$ concentration $\left(45 \pm 18 \mu \mathrm{g} \mathrm{m}^{-3}\right)$ during the APEC reduced by about $30 \%$ compared to that in the before- and after-APEC phases $\left(71 \pm 27 \mu \mathrm{g} \mathrm{m}^{-3}\right.$ versus $78 \pm 29 \mu \mathrm{g} \mathrm{m}^{-3}$; Table 1$)$, mainly because of the reduction of the on-road vehicle numbers, as well as the reduced productivities of power plant and industry. $\mathrm{O}_{3}$ displayed a decreasing trend similar to that of temperature (Fig. 1c). $\mathrm{PM}_{2.5}$ pollution episodes in Beijing showed a periodic cycle of 4-5 days, which is caused by the local weather cycles. Secondary inorganic aerosols (SIA, 


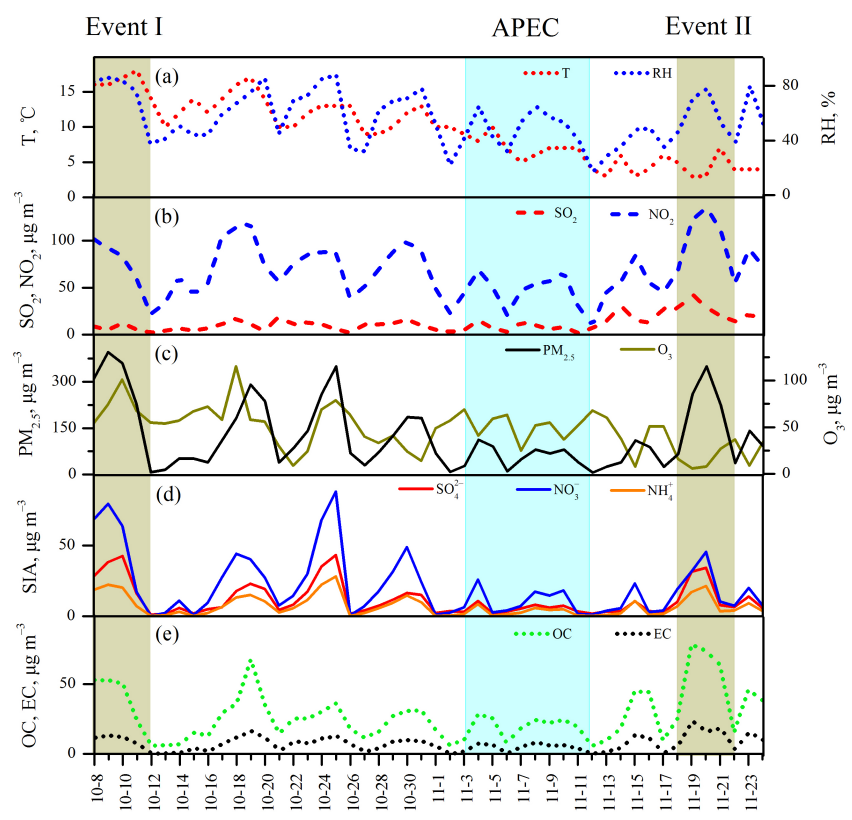

Figure 1. Temporal variations of meteorological conditions, gaseous pollutants and major components of $\mathrm{PM}_{2.5}$ during the 2014 APEC campaign. (The green shadows represent two air pollution events characterized by highest $\mathrm{PM}_{2.5}$ levels before and after APEC, while the blue shadow represents the APEC event).

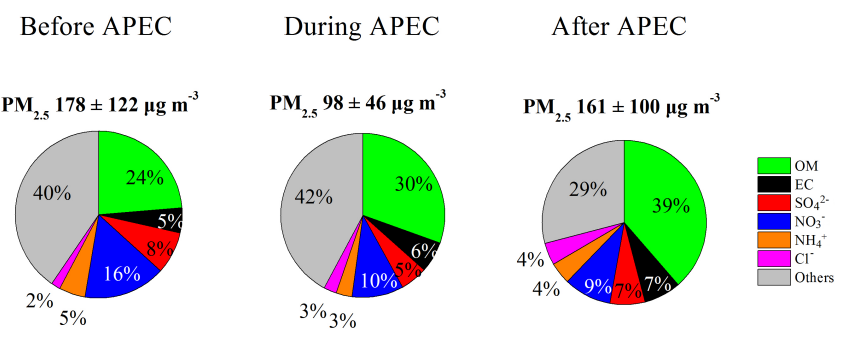

Figure 2. Chemical composition of $\mathrm{PM}_{2.5}$ during the 2014 APEC campaign.

i.e., $\mathrm{SO}_{4}^{2-}, \mathrm{NO}_{3}^{-}$, and $\mathrm{NH}_{4}^{+}$) are major components of $\mathrm{PM}_{2.5}$ and present a temporal variation pattern similar to that of the fine particles (Fig. 1d). In the current work, the mass ratio of $\mathrm{NO}_{3}^{-} / \mathrm{SO}_{4}^{2-}$ in $\mathrm{PM}_{2.5}$ during the whole study time is $1.8 \pm 1.9$ (Table 1), which is in agreement with the ratio (1.62.4) for $\mathrm{PM}_{1}$ observed during the same time by using aerosol mass spectrometry (AMS; Sun et al., 2016). OC and EC of $\mathrm{PM}_{2.5}$ are linearly correlated each other $\left(R^{2}=0.91\right)$ and varied periodically in a cycle similar to SIA (Fig. 1e). The OC / EC ratio during the whole sampling period is $3.3 \pm 0.6$ (range: 2.2-4.7) with no significant differences among the three APEC phases (Table 1), although the source emissions could be largely different.

Figure 2 shows the differences in chemical composition of $\mathrm{PM}_{2.5}$ before, during, and after APEC. $\mathrm{PM}_{2.5}$ is $98 \pm 46 \mu \mathrm{g} \mathrm{m}^{-3}$ during APEC, about $50 \%$ lower than

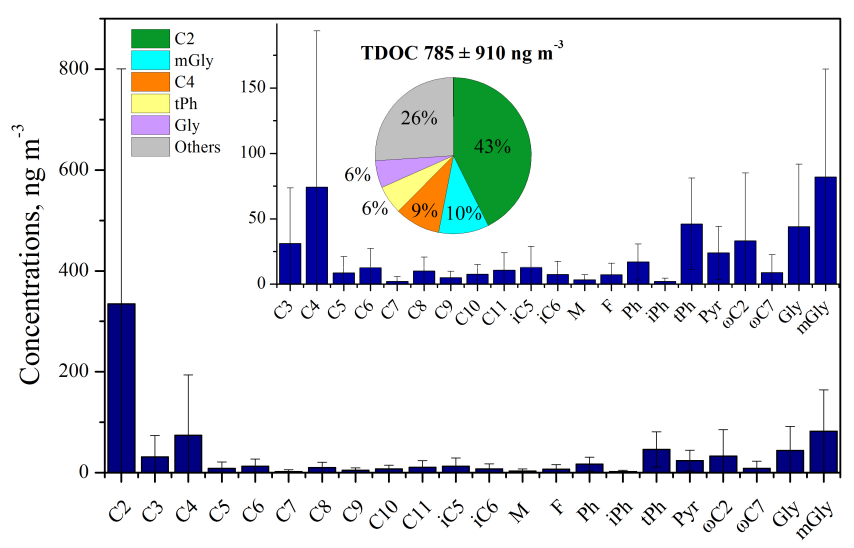

Figure 3. Molecular distributions of dicarboxylic acids and related compounds in $\mathrm{PM}_{2.5}$ of Beijing, China, during the 2014 APEC campaign. The pie chart is the average composition of total detected organic compounds (TDOC) and the top number is the average mass concentration of TDOC of the whole study period.

that before and after APEC $\left(178 \pm 122 \mu \mathrm{g} \mathrm{m}^{-3}\right.$ versus $161 \pm 100 \mu \mathrm{g} \mathrm{m}^{-3}$, respectively). Organic matter (OM) is the most abundant component of the fine particles. Relative abundance of OM (1.6 times OC; Xing et al., 2013) to $\mathrm{PM}_{2.5}$ continuously increases from $24 \%$ before APEC to 30 and $39 \%$ during and after APEC, respectively, although the mass concentration $\left(19 \pm 7.6 \mu \mathrm{g} \mathrm{m}^{-3}\right)$ of OC during APEC is the lowest compared to those before and after APEC $\left(26 \pm 16 \mu \mathrm{g} \mathrm{m}^{-3}\right.$ versus $\left.39 \pm 23 \mu \mathrm{g} \mathrm{m}^{-3}\right)$. Sulfate, nitrate, and ammonium before APEC are $15 \pm 13,28 \pm 26$, and $9.0 \pm 8.0 \mu \mathrm{g} \mathrm{m}^{-3}$ (Table 1) and account for 8,16 , and $5 \%$ of $\mathrm{PM}_{2.5}$, respectively (Fig. 2). Their concentrations decrease to $5.3 \pm 2.8,10 \pm 8.1$, and $3.1 \pm 2.6 \mu \mathrm{g} \mathrm{m}^{-3}$ (Table 1) with the relative contributions to $\mathrm{PM}_{2.5}$ down to 5,10 , and $3 \%$ during APEC, respectively, while after APEC their concentrations increased to $11 \pm 10,15 \pm 13$, and $6.9 \pm 6.4 \mu \mathrm{g} \mathrm{m}^{-3}$ and accounted for 7, 9, and $4 \%$ of $\mathrm{PM}_{2.5}$. Such significant decreases in concentrations of OM and SIA during APEC demonstrate the efficiency of the emission controls. The $\mathrm{OC} / \mathrm{EC}$ ratio is almost constant during the whole period, but the WSOC / OC ratio decreased by $20 \%$ from $0.42 \pm 0.13$ before APEC, $0.38 \pm 0.16$ during APEC to $0.35 \pm 0.17$ after APEC (Table 1). Since WSOC in fine aerosols consists mainly of SOAs (Laskin et al., 2015), the decreasing ratio of WSOC / OC probably indicates reduced SOA production during the campaign.

\subsection{Oxalic acid and related SOA during the Beijing 2014 APEC campaign}

A homogeneous series of dicarboxylic acids $\left(\mathrm{C}_{2}-\mathrm{C}_{11}\right)$, ketocarboxylic acid and $\alpha$-dicarbonyls in the $\mathrm{PM}_{2.5}$ samples were detected. As shown in Table 2, total dicarboxylic acids during the whole study period is $593 \pm 739 \mathrm{ng} \mathrm{m}^{-3}$, which is lower than that observed during the Campaign of Air Quality Re- 


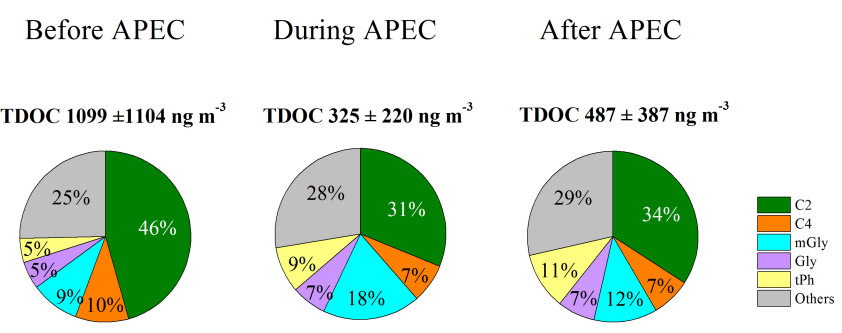

Figure 4. Compositions of total detected organic compounds (TDOC) in $\mathrm{PM}_{2.5}$ during the 2014 APEC campaign.

search in Beijing 2006 (CAREBeijing; average $760 \mathrm{ng} \mathrm{m}^{-3}$ ) and 2007 (average $1010 \mathrm{ng} \mathrm{m}^{-3}$; Ho et al., 2010, 2015) and the averaged wintertime concentration reported by a previous study on 14 Chinese cities (904 $\mathrm{ng} \mathrm{m}^{-3}$; Ho et al., 2007). Total keto-carboxylic acid is $66 \pm 81 \mathrm{ng} \mathrm{m}^{-3}$, while total dicarbonyl is $126 \pm 115 \mathrm{ng} \mathrm{m}^{-3}$ (Table 2). These values are higher than those during CAREBeijing 2006 and 2007 (Ho et al., 2010, 2015), but close to the value observed for the 14 Chinese megacities (Ho et al., 2007). Being similar to those previous observations, oxalic acid $\left(\mathrm{C}_{2}\right)$ is the most abundant diacid in the 2014 APEC samples, with an average of $334 \pm 461 \mathrm{ng} \mathrm{m}^{-3}$ (range: 10-2127 $\mathrm{ng} \mathrm{m}^{-3}$, Table 2) during the whole campaign, followed by methylglyoxal (mGly), succinin acid $\left(\mathrm{C}_{4}\right)$, terephthalic acid $(\mathrm{tPh})$, and glyoxal (Gly). These five species account for 43, 10, 9, 6 and $6 \%$ of total detected organic compounds (TDOC), respectively (Fig. 3).

As seen in Fig. 4, TDOC in $\mathrm{PM}_{2.5}$ are $1099 \pm 1104$, $325 \pm 220$, and $487 \pm 387 \mathrm{ng} \mathrm{m}^{-3}$ before, during, and after APEC, respectively. In comparison with those before APEC, TDOC during APEC decreased by $71 \%$. Oxalic acid $\left(\mathrm{C}_{2}\right)$ is the leading species among the detected organic compounds and accounted for 46,31 , and $34 \%$ of TDOC during the three phases, respectively (Fig. 4). $\mathrm{C}_{2}$ is an end product of precursors that are photochemically oxidized in aerosol aqueous phase via either oxidation of small compounds containing two carbon atoms or decomposition of larger compounds containing three or more carbon atoms. Thus the mass ratio of $\mathrm{C}_{2}$ to TDOC is indicative of aerosol aging (Wang et al., 2012; Ho et al., 2015). As shown in Fig. 4, the highest proportion of $\mathrm{C}_{2}$ before APEC suggests that organic aerosols during this period are more oxidized, compared to those during and after APEC. Gly and methylglyoxal (mGly) are the precursors of $\mathrm{C}_{2}$. Mass ratios of both compounds to TDOC are lowest before APEC (Fig. 4), further indicating enhanced SOA production during this period.

\subsection{Formation mechanism of oxalic acid}

\subsubsection{Correlation of oxalic acid with temperature, relative humidity $(\mathbf{R H})$, aerosol liquid water content (ALWC) and acidity and sulfate}

A few studies have pointed out that aerosol aqueous phase oxidation is a major formation pathway for oxalic acid (Yu et al., 2005; van Pinxteren et al., 2014; Bikkina et al., 2015; Tilgner and Herrmann, 2010). To explore the formation mechanism of oxalic acid, we calculated ALWC and acidity (i.e., proton concentration, $\left[\mathrm{H}^{+}\right]$) of $\mathrm{PM}_{2.5}$ aerosols by using ISOROPPIA-II model (Weber et al., 2016). As shown in Fig. 5, during the entire period $\mathrm{C}_{2}$ showed a strong linear correlation with sulfate $\left(R^{2}=0.70 \mathrm{Fig}\right.$. 5a), which is consistent with the measurements observed in Xi' an (Wang et al., 2012) and other Chinese cities (Yu et al., 2005). Previous studies on particle morphology showed that sulfate particles internally mix with SOA in Beijing, especially on humid haze days (Li et al., 2010, 2011), which probably indicates that they are formed via similar aqueous phase pathways (Wang et al., 2016b). In addition, a robust correlation was also found for $\mathrm{C}_{2}$ with $\mathrm{RH}\left(R^{2}=0.64\right.$, Fig. 5b) and $\operatorname{ALWC}\left(R^{2}=0.61\right.$, Fig. 5c), indicating that humid conditions are favorable for the aqueous phase formation of $\mathrm{C}_{2}$, which is most likely due to an enhanced gas-to-aerosol aqueous phase partitioning of the precursors (e.g., Gly and mGly; Fu et al., 2008; G. Wang et al., 2015).

$\mathrm{NH}_{4}^{+}, \mathrm{NO}_{3}^{-}$, and $\mathrm{SO}_{4}^{2-}$ are the dominant cation and anions of fine particles in Beijing (Guo et al., 2014; Zhang et al., $2015)$ and the molar ratio of $\left[\mathrm{NH}_{4}^{+}\right]$to $\left[\mathrm{NO}_{3}^{-}\right]+\left[\mathrm{SO}_{4}^{2-}\right]$ in this study is 1.1. Thus it is plausible that $\mathrm{SO}_{4}^{2-}$ during the APEC campaign largely existed as ammonium bisulfate, resulting in a strong linear correlation between $\left[\mathrm{H}^{+}\right]$and $\mathrm{SO}_{4}^{2-}$ with a molar slope of 1.03 (Fig. 5d; Zhang et al., 2007). In addition, $\left[\mathrm{H}^{+}\right]$shows a significant positive correlation with $\mathrm{C}_{2}\left(R^{2}=0.84\right.$; Fig. 5 e $)$, possibly due to the fact that acidic conditions are favorable for the formation of $\mathrm{C}_{2}$ precursors. For example, Surratt et al. $(2007,2010)$ found that aerosol acidity can promote the formation of biogenic SOA (BSOA) derived from isoprene oxidation, such as 2-methylglyceric acid, Gly and mGly. These BSOA precursors can be further oxidized into $C_{2}$ (Meng et al., 2014; Wang et al., 2009).

There is a significant positive correlation $\left(R^{2}=0.58\right.$, $p<0.001)$ between the mass ratios of $\mathrm{C}_{2} /$ TDOC and ambient temperatures (Fig. 5f), which is similar to the results found by previous researchers (Ho et al., 2007; Strader et al., 1999), indicating that organic aerosols are more aged under a higher temperature condition (Erven et al., 2011; Carlton et al., 2009). Thus, compared with those before APEC, the lower $\mathrm{C}_{2} /$ TDOC ratios (31 and $34 \%$ (Fig. 4) during and after APEC respectively) can be ascribed in part to the relatively lower temperature conditions that are not favorable for oxidation of the precursors to produce oxalic acid (13 \pm 2.6 , 

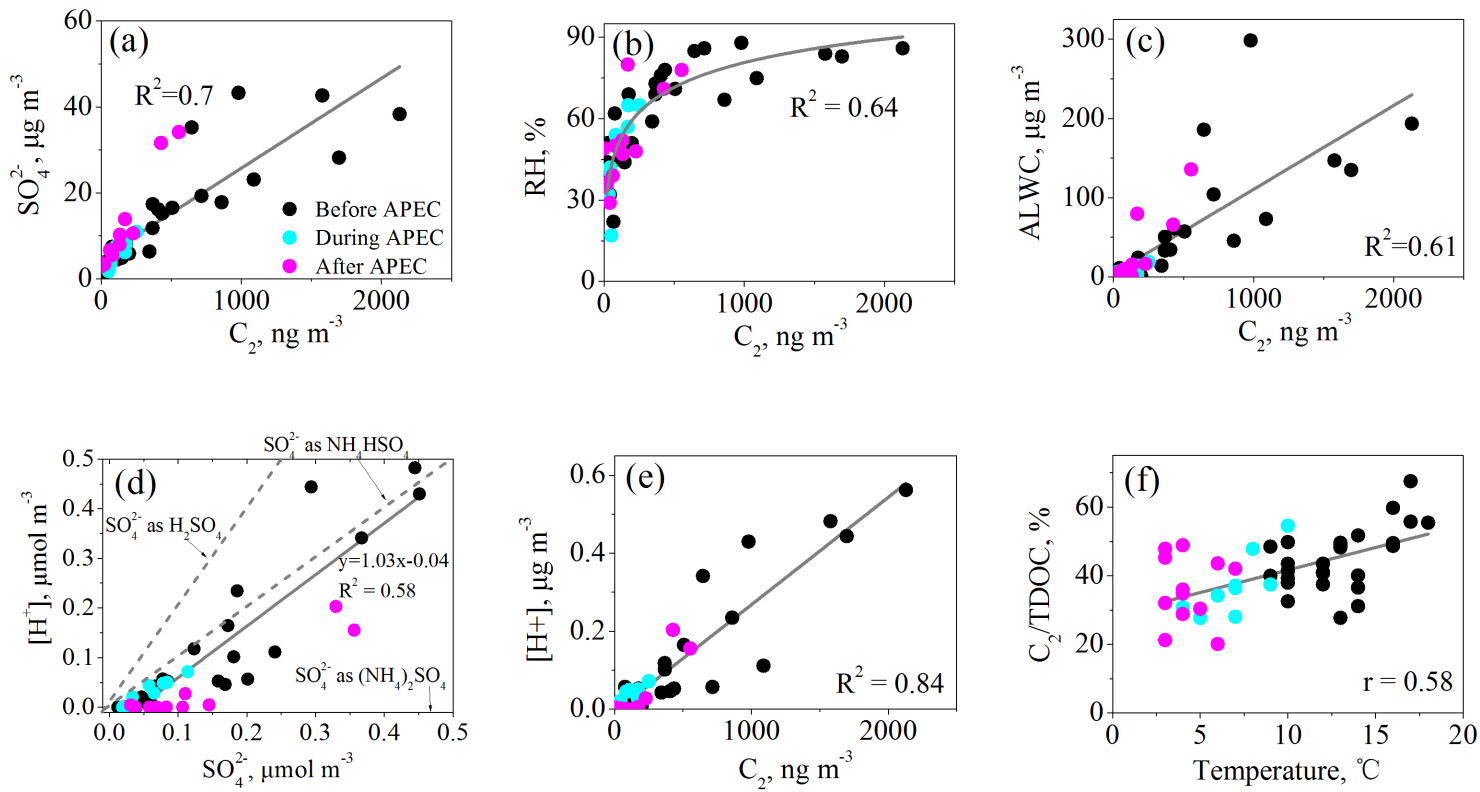

Figure 5. Correlation analysis for oxalic acid $\left(\mathrm{C}_{2}\right)$ and sulfate in $\mathrm{PM}_{2.5}$ during the whole 2014 APEC campaign. (a-c) Concentrations of $\mathrm{C}_{2}$ with sulfate, relative humidity $(\mathrm{RH})$, and aerosol liquid water content (ALWC); (d, e) sulfate and $\mathrm{C}_{2}$ with aerosol acidity $\left[\mathrm{H}^{+}\right]$and (f) temperature with mass ratio of $\mathrm{C}_{2}$ to total detected organic compounds $\left(\mathrm{C}_{2} /\right.$ TDOC).

Table 3. Linear correlation coefficients of $\delta^{13} \mathrm{C}$ of $\mathrm{C}_{2}$ with $\mathrm{C}_{2} / \omega \mathrm{C}_{2}, \mathrm{C}_{2} / \mathrm{mGly}$, and TDOC / WSOC.

\begin{tabular}{rrrr}
\hline & $\mathrm{C}_{2} / \omega \mathrm{C}_{2}$ & $\mathrm{C}_{2} / \mathrm{mGly}$ & $\mathrm{TDOC} / \mathrm{WSOC}$ \\
\hline$\delta^{13} \mathrm{C}$ & $0.49^{* *}$ & $0.35^{*}$ & $0.41^{*}$ \\
\hline${ }^{* *} p<0.01 ;{ }^{*} p<0.05$. & &
\end{tabular}

$7.0 \pm 1.7$ and $4.3 \pm 1.3{ }^{\circ} \mathrm{C}$ in the before-, during- and afterAPEC periods, respectively; Table 1).

\subsubsection{Temporal variation in stable carbon isotopic composition of oxalic acid}

To further discuss the formation mechanism of $\mathrm{C}_{2}$, we investigated the temporal variations of concentration and stable carbon isotopic composition of $\mathrm{C}_{2}$ in the $\mathrm{PM}_{2.5}$ samples (Fig. 6). Previous studies have demonstrated that Gly, mGly, glyoxylic acid $\left(\omega \mathrm{C}_{2}\right)$, and pyruvic acid (Pyr) are the precursors of $\mathrm{C}_{2}$ (Carlton et al., 2006, 2007; Ervens et al., 2004; Wang et al., 2012). Thus, higher mass ratios of $C_{2}$ to its precursors indicate that organic aerosols are more oxidized (Wang et al., 2010). As shown in Table $3, \delta^{13} \mathrm{C}$ of $\mathrm{C}_{2}$ in this work positively correlated with the mass ratios of $\mathrm{C}_{2} / \omega \mathrm{C}_{2}$, $\mathrm{C}_{2}$ / mGly, and TDOC / WSOC, demonstrating an enrichment of ${ }^{13} \mathrm{C}$ during the aerosol oxidation process. Because decomposition (or breakdown) of larger molecular weight precursors in aerosol aqueous phase is the dominant formation pathway for $\mathrm{C}_{2}$ in the aerosol ageing process (Kawamura et al., 2016; Gensch et al., 2014; Kirillova et al., 2013), during which organic compounds release $\mathrm{CO}_{2} / \mathrm{CO}$ by reaction with $\mathrm{OH}$ radical and other oxidants, resulting in the evolved species enriched with lighter isotope $\left({ }^{12} \mathrm{C}\right)$ and the remaining substrate enriched in ${ }^{13} \mathrm{C}$ due to kinetic isotope effects (KIE; Hoefs, 1997; Rudolph et al., 2002).

A $72 \mathrm{~h}$ backward trajectory analysis showed that air masses that moved to Beijing during the whole sampling period can roughly be categorized into three types (Fig. 6a; all trajectories during the entire study period can be found in the Supplement). (1) Polluted type, by which air masses originated inland and east coastal China and moved slowly into Beijing within $72 \mathrm{~h}$ from its southern regions, i.e., Henan, Shandong, and Jiangsu provinces. This type of air mass mostly occurred before APEC with high $\mathrm{PM}_{2.5}$ concentrations. Air pollution has been widely distributed in the three provinces (Wei et al., 2016); thus aerosols transported by this type of air mass are of regional characteristics. (2) Mixed type, by which air masses originated from Mongolia and North China, and moved quickly into Hebei province and then turned back to Beijing. The air in Mongolia and North China was clean but polluted in Hebei province, which is adjacent to Beijing. This type of air mass is a mixture of clean and polluted air and is thus named mixed type. Since the resident time of the mixed type of air mass within Hebei province is very short, thus aerosols transported by this type of air mass are of local characteristics and relatively fresh. (3) Clean type, by which air masses originated from Siberia and moved rapidly into Beijing directly via long-range transport. Aerosols from the clean type of air masses are much 
Table 4. Meteorological parameters and chemical compositions $\left(\mu \mathrm{g} \mathrm{m}^{-3}\right)$ of two maximum $\mathrm{PM}_{2.5}$ between two pollution episodes in Beijing.

\begin{tabular}{lrrrrrrrr}
\hline & $T\left({ }^{\circ} \mathrm{C}\right)$ & $\mathrm{RH}(\%)$ & $\mathrm{V}^{\mathrm{a}}(\mathrm{km})$ & $\mathrm{PM}_{2.5}$ & OC & EC & SIA $^{\mathrm{b}}$ & TDOC $^{\mathrm{c}}$ \\
\hline $\begin{array}{l}\text { Event I } \\
(8 / 10-11 / 10, \text { Before APEC })\end{array}$ & $16.7 \pm 0.8$ & $82 \pm 4$ & $1.5 \pm 0.5$ & $349 \pm 57$ & $45 \pm 12$ & $12 \pm 2$ & $106 \pm 39$ & $2749 \pm 1357$ \\
$\begin{array}{l}\text { Event II } \\
(18 / 11-21 / 11, \text { After APEC })\end{array}$ & $4.5 \pm 1.7$ & $62 \pm 13$ & $3.5 \pm 1.5$ & $259 \pm 102$ & $60 \pm 21$ & $17 \pm 6$ & $60 \pm 32$ & $831 \pm 400$ \\
\hline
\end{tabular}

${ }^{a}$ V: visibility. ${ }^{b}$ SIA: secondary inorganic aerosols (the sum of sulfate, nitrate, and ammonium). ${ }^{\mathrm{c}}$ TDOC: total detected organic compounds.

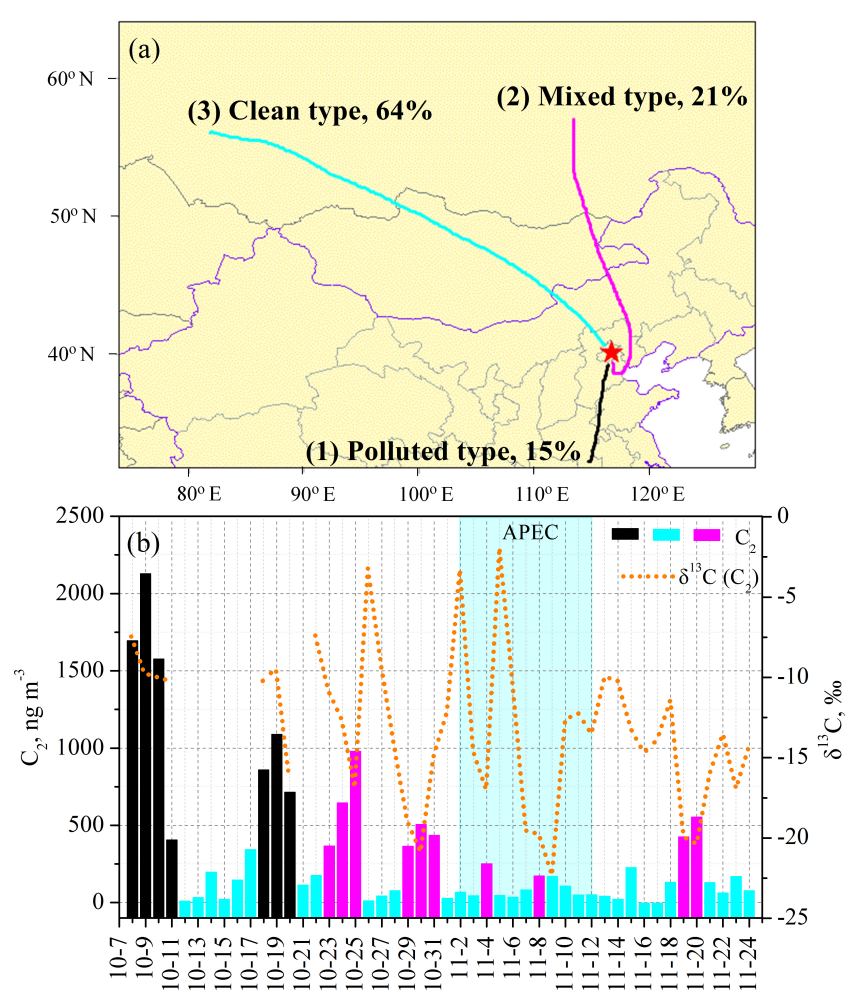

Figure 6. (a) $72 \mathrm{~h}$ backward trajectories determined by the National Oceanic and Atmospheric Administration Hybrid Single Particle Lagrangian Integrated Trajectory (HYSPLIT) model arriving at the sampling site to reveal the major air-mass flow types during the study period. Northwesterly wind (light blue) was most frequent (64\%), followed by northerly (21\%, pink) and southerly (15\%, black), and these are defined as clean, mixed, and polluted types, respectively (see the definitions in the text and the trajectories with a $6 \mathrm{~h}$ interval in the Supplement); (b) time series of $\delta^{13} \mathrm{C}$ values and concentration of oxalic acid during the whole study period (colors in Fig. 6a are corresponding to those in Fig. 6b).

more aged, while those from the mixed type of air masses are fresh. Since severe air pollution is widespread in the southern regions, gas-to-aerosol phase partitioning of precursors and subsequent aerosol-phase oxidation to produce SOA including $\mathrm{C}_{2}$ continuously proceed during the air-mass movement. However, such a partition for producing SOA is not significant when air masses move from Siberia, Mongolia, and northern China because of the much less abundant VOCs. Instead, aerosols in the clean air masses are continuously oxidized, during which $\mathrm{C}_{2}$ is produced by photochemical decomposition of larger molecular weight precursors. Therefore, $\mathrm{C}_{2}$ in $\mathrm{PM}_{2.5}$ transported by the mixed type air masses is not only fresh and abundant but also enriched in ${ }^{12} \mathrm{C}$, whereas $\mathrm{C}_{2}$ in $\mathrm{PM}_{2.5}$ transported by the clean type air masses is aged, less abundant, and enriched in ${ }^{13} \mathrm{C}$ due to $\mathrm{KIE}$ effects, as illustrated by the pink and light blue columns in Fig. 6b, respectively. $\mathrm{C}_{2}$ in $\mathrm{PM}_{2.5}$ transported by the polluted type of air mass is most abundant compared with that in other two types of air mass, which is not only due to the severe air pollution in the Henan, Shandong, and Jiangsu provinces but also due to the enhanced photochemical oxidation under the humid, higher temperature and stagnant conditions that occurred mostly before APEC, as discussed previously. Therefore, $\mathrm{C}_{2}$ in the polluted type of air masses is not only abundant but also enriched in ${ }^{13} \mathrm{C}$ (see black columns in Fig. 6b).

\subsection{Different chemical characteristics of $\mathbf{P M}_{2.5}$ between two severe haze events}

From Fig. 1 and Table 4, it can be found that $\mathrm{PM}_{2.5}$ showed two equivalent maxima on 9 October and 20 November during the whole study period. However, the chemical compositions of $\mathrm{PM}_{2.5}$ during these two pollution events are significantly different. As shown in Fig. 7a, relative abundances of SIA (sum of $\mathrm{SO}_{4}^{2-}, \mathrm{NO}_{3}^{-}$, and $\mathrm{NH}_{4}^{+}$) to $\mathrm{PM}_{2.5}$ are $30 \%$ during event I and $23 \%$ during event II. The relative abundance of OM (21\%, Fig. 7a) during event I is lower than that $(37 \%)$ during event II (Fig. 7b). In contrast, the ratios of WSOC / OC and TDOC / OC are higher in event I than in event II, which is consistent with lower levels of $\mathrm{O}_{3}$ after APEC (Table 1), suggesting a weaker photochemical oxidation capacity during event II. Organic biomarkers in the $\mathrm{PM}_{2.5}$ samples have been measured for the source apportionment (Wang et al., 2016a) and cited here to further identify the difference in chemical composition of $\mathrm{PM}_{2.5}$ between the two events. Levoglucosan is a key tracer for biomass burning smoke. The mass ratio of levoglucosan to $\mathrm{OC}$ in $\mathrm{PM}_{2.5}$ (Lev / OC) is comparable between the two events, suggesting a similar level of contributions of biomass burning emission to $\mathrm{PM}_{2.5}$ before and after APEC. However, the mass ratios of polycyclic aromatic hydrocarbons (PAHs) and 

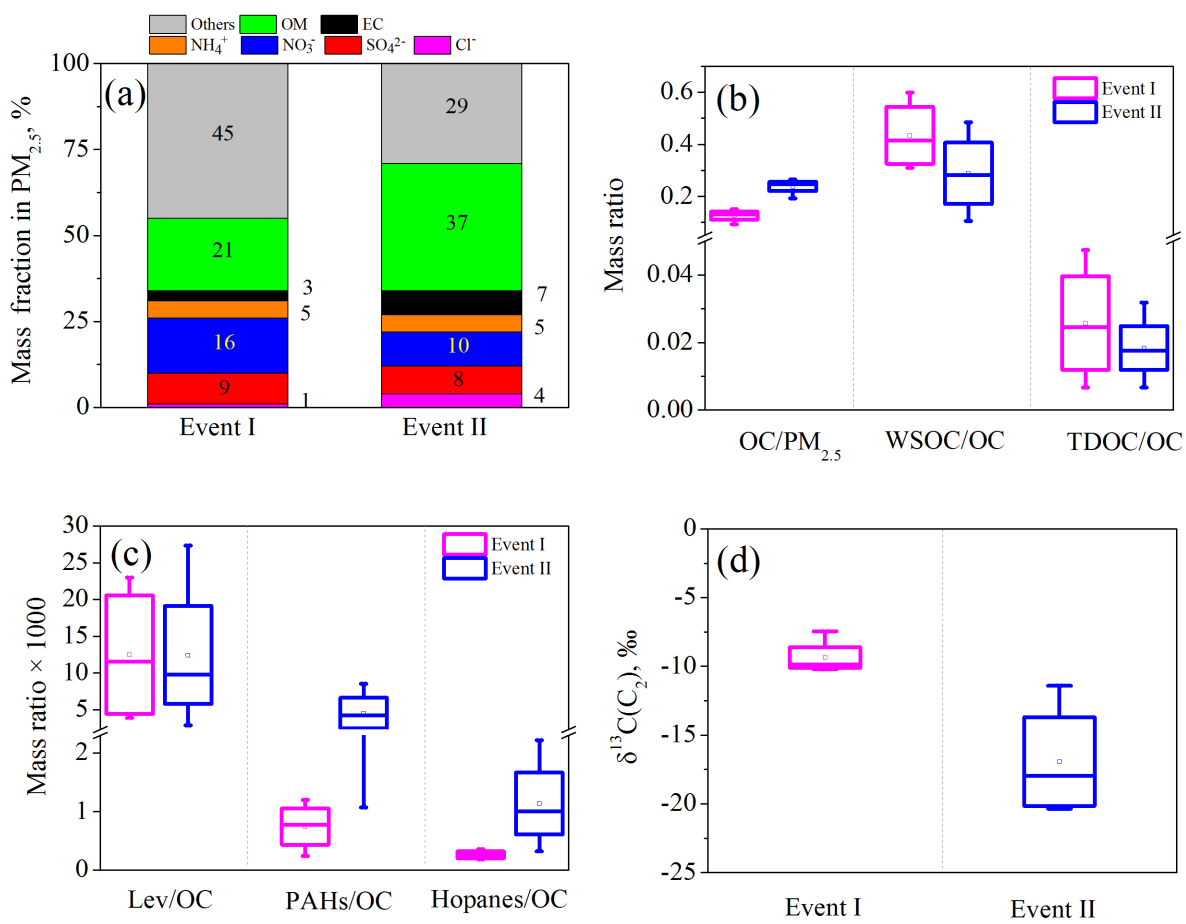

Figure 7. Comparison of chemical composition of $\mathrm{PM}_{2.5}$ during two air pollution events. (a) Percentages of major species in $\mathrm{PM}_{2.5}$; (b, c) mass ratios of major species and organic tracers in $\mathrm{PM}_{2.5}$; (d) stable carbon isotope composition of oxalic acid $\left(\mathrm{C}_{2}\right)($ data about levoglucosan (Lev), PAHs, and hopanes are cited from Wang et al., 2016a).

hopanes to OC are lower in event I than those in event II (Fig. 7c), which again demonstrates the enhanced emissions from coal burning for house heating, because these compounds are key tracers of coal burning smokes (Wang et al., 2006). As seen in Fig. $7 d, C_{2}$ in event $I$ was enriched in ${ }^{13} \mathrm{C}$. Such relatively more abundant SIA, WSOC, and TDOC and heavier $\mathrm{C}_{2}$ in $\mathrm{PM}_{2.5}$ clearly demonstrate that $\mathrm{PM}_{2.5}$ during event $\mathrm{I}$ is enriched with secondary products while the fine particles during event II are enriched with primary compounds. After-APEC house heating activities including residential coal burning were activated, which emitted huge amounts of $\mathrm{SO}_{2}, \mathrm{NO}_{x}$, and VOCs as well as primary particles, resulting in both absolute concentrations and relative abundances of $\mathrm{CO}$ and EC 30-40 \% higher after APEC than before APEC (see Table 1). Li et al. (2015) reported that VOCs in Beijing were 86 ppbv before APEC, 48 ppbv during APEC, and $73 \mathrm{ppbv}$ after APEC. As shown in Table 4, temperature $\left(16.7 \pm 0.8^{\circ} \mathrm{C}\right.$ for event $\mathrm{I}$ and $4.5 \pm 1.7^{\circ} \mathrm{C}$ for event II) and relative humidity (RH; $82 \pm 4$ for event I and $62 \pm 13 \%$ for event II) are lower during event II than during event I. Moreover, air masses arriving in Beijing during event II are the mixed type, of which the resident time in Hebei province is short. Compared with those in event I, such colder and drier conditions and a short reaction time during event II are unfavorable for photochemical oxidation, resulting in SOA not only less abundant but also enriched with lighter ${ }^{12} \mathrm{C}$ during event II, although VOC levels are comparable before and after APEC.

\section{Summary and conclusion}

Temporal variations in molecular distribution of SIA, dicarboxylic acids, ketoacids, $\alpha$-dicarbonyl, and stable carbon isotopic composition $\left(\delta^{13} \mathrm{C}\right)$ of $\mathrm{C}_{2}$ in $\mathrm{PM}_{2.5}$ collected in Beijing before, during and after the 2014 APEC were investigated. Absolute concentrations and relative abundances of SIA and $\mathrm{C}_{2}$ in $\mathrm{PM}_{2.5}$ are highest before APEC, followed by those after and during APEC, suggesting that the fine aerosols before APEC are enriched with secondary products, mainly due to an enhanced photochemical oxidation under the warm, humid and stagnant conditions. Concentrations of SIA, oxalic acid and related SOA in $\mathrm{PM}_{2.5}$ during APEC are 2-4 times lower than those before APEC, which can be ascribed to the effective emission controls and the favorable meteorological conditions that brought clean air from Siberia and Mongolia into Beijing.

Positive correlations of $\mathrm{C}_{2}$ with sulfate mass, $\mathrm{RH}$, ALWC, and aerosol acidity indicate that the $\mathrm{C}_{2}$ formation pathway is involved in acid-catalyzed aerosol aqueous phase oxidation. SIA, $\mathrm{C}_{2}$, and related SOA in the polluted types of air mass are abundant with $\mathrm{C}_{2}$ enriched in ${ }^{13} \mathrm{C}$. On the contrary, those in the clean types of air mass are much less abundant, although 
$\mathrm{C}_{2}$ is also enriched in ${ }^{13} \mathrm{C}$. By comparing the chemical composition of $\mathrm{PM}_{2.5}$ and $\delta^{13} \mathrm{C}$ values of $\mathrm{C}_{2}$ in two events that are characterized by the highest loadings of $\mathrm{PM}_{2.5}$ before and after APEC, we further found that compared with those before APEC fine aerosols after APEC are enriched with primary species and $\mathrm{C}_{2}$ is depleted in heavier ${ }^{13} \mathrm{C}$, although $\mathrm{SO}_{2}, \mathrm{NO}_{x}$, and VOCs are abundant during the heating season, again demonstrating the important role of meteorological conditions in the secondary aerosol formation process, which are warmer, humid, and stagnant before APEC and result in secondary species being much more abundant than those during and after APEC.

\section{The Supplement related to this article is available online at doi:10.5194/acp-17-981-2017-supplement.}

Acknowledgement. This work was financially supported by the Strategic Priority Research Program of the Chinese Academy of Sciences (grant no. XDB05020401), the China National Natural Science Founds for Distinguished Young Scholars (grant no. 41325014), and the program from the National Nature Science Foundation of China (no. 41405122, 91544226 and 41375132).

Edited by: R. Zhang

Reviewed by: three anonymous referees

\section{References}

Beijing Municipal Bureau of Statistics: available at: http://www.bjstats.gov.cn/tjsj/yjdsj/rk/2014/201511/t20151124_ 323864.html, 2015.

Bikkina, S., Kawamura, K., and Miyazaki, Y.: Latitudinal distributions of atmospheric dicarboxylic acids, oxocarboxylic acids, and $\alpha$-dicarbonyls over the western North Pacific: Sources and formation pathways, J. Geophys. Res.-Atmos., 120, 5010-5035, doi:10.1002/2014jd022235, 2015.

Carlton, A. G., Turpin, B. J., Lim, H.-J., Altieri, K. E., and Seitzinger, S.: Link between isoprene and secondary organic aerosol (SOA): Pyruvic acid oxidation yields low volatility organic acids in clouds, Geophys. Res. Lett., 33, L06822, doi:10.1029/2005g1025374, 2006.

Carlton, A. G., Turpin, B. J., Altieri, K. E., Seitzinger, S., Reff, A., Lim, H.-J., and Ervens, B.: Atmospheric oxalic acid and SOA production from glyoxal: Results of aqueous photooxidation experiments, Atmos. Environ., 41, 7588-7602, doi:10.1016/j.atmosenv.2007.05.035, 2007.

Carlton, A. G., Wiedinmyer, C., and Kroll, J. H.: A review of Secondary Organic Aerosol (SOA) formation from isoprene, Atmos. Chem. Phys., 9, 4987-5005, doi:10.5194/acp-9-4987-2009, 2009.

Cheng, C., Wang, G., Meng, J., Wang, Q., Cao, J., Li, J., and Wang, J.: Size-resolved airborne particulate oxalic and related secondary organic aerosol species in the urban atmo- sphere of Chengdu, China, Atmos. Res., 161-162, 134-142, doi:10.1016/j.atmosres.2015.04.010, 2015.

Chow, J. C., Watson, J. G., Chen, L.-W. A., Chang, M. O., Robinson, N. F., Trimble, D., and Kohl, S.: The IMPROVE_A temperature protocol for thermal/optical carbon analysis: maintaining consistency with a long-term database, J. Air Waste Manage. Assoc., 57, 1014-1023, 2007.

Ervens, B., Feingold, G., Frost, G. J., and Kreidenweis, S. M.: A modeling study of aqueous production of dicarboxylic acids: 1. Chemical pathways and speciated organic mass production, J. Geophys. Res.-Atmos., 109, D15206, doi:10.1029/2003JD004387, 2004.

Ervens, B., Turpin, B. J., and Weber, R. J.: Secondary organic aerosol formation in cloud droplets and aqueous particles (aqSOA): a review of laboratory, field and model studies, Atmos. Chem. Phys., 11, 11069-11102, doi:10.5194/acp-1111069-2011, 2011.

Fu, T.-M., Jacob, D. J., Wittrock, F., Burrows, J. P., Vrekoussis, M., and Henze, D. K.: Global budgets of atmospheric glyoxal and methylglyoxal, and implications for formation of secondary organic aerosols, J. Geophys. Res., 113, D15303, doi:10.1029/2007jd009505, 2008.

Gensch, I., Kiendler-Scharr, A., and Rudolph, J.: Isotope ratio studies of atmospheric organic compounds: Principles, methods, applications and potential, Int. J. Mass Spectrom., 365-366, 206221, doi:10.1016/j.ijms.2014.02.004, 2014.

Guo, S., Hu, M., Zamora, M. L., Peng, J., Shang, D., Zheng, J., Du, Z., Wu, Z., Shao, M., Zeng, L., Molina, M. J., and Zhang, R.: Elucidating severe urban haze formation in China, P. Natl. Acad. Sci. USA, 111, 17373-17378, doi:10.1073/pnas.1419604111, 2014.

Hennigan, C. J., Izumi, J., Sullivan, A. P., Weber, R. J., and Nenes, A.: A critical evaluation of proxy methods used to estimate the acidity of atmospheric particles, Atmos. Chem. Phys., 15, 27752790, doi:10.5194/acp-15-2775-2015, 2015.

Ho, K. F., Cao, J. J., Lee, S. C., Kawamura, K., Zhang, R. J., Chow, J. C., and Watson, J. G.: Dicarboxylic acids, ketocarboxylic acids, and dicarbonyls in the urban atmosphere of China, J. Geophys. Res., 112, D22S27, doi:10.1029/2006jd008011, 2007.

Ho, K. F., Lee, S. C., Ho, S. S. H., Kawamura, K., Tachibana, E., Cheng, Y., and Zhu, T.: Dicarboxylic acids, ketocarboxylic acids, $\alpha$-dicarbonyls, fatty acids, and benzoic acid in urban aerosols collected during the 2006 Campaign of Air Quality Research in Beijing (CAREBeijing-2006), J. Geophys. Res., 115, D19312, doi:10.1029/2009jd013304, 2010.

Ho, K. F., Huang, R.-J., Kawamura, K., Tachibana, E., Lee, S. C., Ho, S. S. H., Zhu, T., and Tian, L.: Dicarboxylic acids, ketocarboxylic acids, $\alpha$-dicarbonyls, fatty acids and benzoic acid in $\mathrm{PM}_{2.5}$ aerosol collected during CAREBeijing-2007: an effect of traffic restriction on air quality, Atmos. Chem. Phys., 15, 31113123, doi:10.5194/acp-15-3111-2015, 2015.

Hoefs, J. and Hoefs, J.: Stable isotope geochemistry, Springer, 1997. Huang, R. J., Zhang, Y., Bozzetti, C., Ho, K. F., Cao, J. J., Han, Y., Daellenbach, K. R., Slowik, J. G., Platt, S. M., Canonaco, F., Zotter, P., Wolf, R., Pieber, S. M., Bruns, E. A., Crippa, M., Ciarelli, G., Piazzalunga, A., Schwikowski, M., Abbaszade, G., SchnelleKreis, J., Zimmermann, R., An, Z., Szidat, S., Baltensperger, U., El Haddad, I., and Prevot, A. S.: High secondary aerosol contribution to particulate pollution during haze events in China, Nature, 514, 218-222, doi:10.1038/nature13774, 2014. 
Kawamura, K. and Watanabe, T.: Determination of stable carbon isotopic compositions of low molecular weight dicarboxylic acids and ketocarboxylic acids in atmospheric aerosol and snow samples, Anal. Chem., 76, 5762-5768, 2004.

Kawamura, K. and Bikkina, S.: A review of dicarboxylic acids and related compounds in atmospheric aerosols: Molecular distributions, sources and transformation, Atmos. Res., 170, 140-160, doi:10.1016/j.atmosres.2015.11.018, 2016.

Kirillova, E. N., Andersson, A., Sheesley, R. J., Kruså, M., Praveen, P. S., Budhavant, K., Safai, P. D., Rao, P. S. P., and Gustafsson, Ö.: 13C- and14C-based study of sources and atmospheric processing of water-soluble organic carbon (WSOC) in South Asian aerosols, J. Geophys. Res.-Atmos., 118, 614-626, doi:10.1002/jgrd.50130, 2013.

Laskin, A., Laskin, J., and Nizkorodov, S. A.: Chemistry of Atmospheric Brown Carbon, Chem. Rev., 115, 4335-4382, doi:10.1021/cr5006167, 2015.

Li, J., Xie, S. D., Zeng, L. M., Li, L. Y., Li, Y. Q., and Wu, R. R.: Characterization of ambient volatile organic compounds and their sources in Beijing, before, during, and after Asia-Pacific Economic Cooperation China 2014, Atmos. Chem. Phys., 15, 7945-7959, doi:10.5194/acp-15-7945-2015, 2015.

Li, W. and Shao, L.: Mixing and water-soluble characteristics of particulate organic compounds in individual urban aerosol particles, J. Geophys. Res., 115, D02301, doi:10.1029/2009jd012575, 2010

Li, W., Zhou, S., Wang, X., Xu, Z., Yuan, C., Yu, Y., Zhang, Q., and Wang, W.: Integrated evaluation of aerosols from regional brown hazes over northern China in winter: Concentrations, sources, transformation, and mixing states, J. Geophys. Res., 116, D09301, doi:10.1029/2010jd015099, 2011.

Ma, Y., Brooks, S. D., Vidaurre, G., Khalizov, A. F., Wang, L., and Zhang, R.: Rapid modification of cloud-nucleating ability of aerosols by biogenic emissions, Geophys. Res. Lett., 40, 6293 6297, doi:10.1002/2013g1057895, 2013.

Meng, J., Wang, G., Li, J., Cheng, C., Ren, Y., Huang, Y., Cheng, Y., Cao, J., and Zhang, T.: Seasonal characteristics of oxalic acid and related SOA in the free troposphere of Mt. Hua, central China: implications for sources and formation mechanisms, Sci. Total Environ., 493, 1088-1097, doi:10.1016/j.scitotenv.2014.04.086, 2014.

$\mathrm{Mu}, \mathrm{Q}$. and Zhang, S.: An evaluation of the economic loss due to the heavy haze during January 2013 in China, China Environmental Science, 33, 2087-2094, 2013.

Myriokefalitakis, S., Tsigaridis, K., Mihalopoulos, N., Sciare, J., Nenes, A., Kawamura, K., Segers, A., and Kanakidou, M.: Incloud oxalate formation in the global troposphere: a 3-D modeling study, Atmos. Chem. Phys., 11, 5761-5782, doi:10.5194/acp11-5761-2011, 2011.

Peng, J., Hu, M., Guo, S., Du, Z., Zheng, J., Shang, D., Zamora, M. L., Zeng, L., Shao, M., and Wu, Y.-S.: Markedly enhanced absorption and direct radiative forcing of black carbon under polluted urban environments, P. Natl. Acad. Sci USA, 113, 42664271, 2016.

Rudolph, J., Czuba, E., Norman, A., Huang, L., and Ernst, D.: Stable carbon isotope composition of nonmethane hydrocarbons in emissions from transportation related sources and atmospheric observations in an urban atmosphere, Atmos. Environ., 36, 1173$1181,2002$.
Sorooshian, A., Lu, M.-L., Brechtel, F. J., Jonsson, H., Feingold, G., Flagan, R. C., and Seinfeld, J. H.: On the Source of Organic Acid Aerosol Layers above Clouds, Environ. Sci. Technol., 41, 4647-4654, doi:10.1021/es0630442, 2007.

Strader, R., Lurmann, F., and Pandis, S. N.: Evaluation of secondary organic aerosol formation in winter, Atmos. Environ., 33, 48494863, 1999.

Sullivan, R. C. and Prather, K. A.: Investigations of the Diurnal Cycle and Mixing State of Oxalic Acid in Individual Particles in Asian Aerosol Outflow, Environ. Sci. Technol., 41, 8062-8069, doi:10.1021/es071134g, 2007.

Sun, Y., Wang, Z., Wild, O., Xu, W., Chen, C., Fu, P., Du, W., Zhou, L., Zhang, Q., Han, T., Wang, Q., Pan, X., Zheng, H., Li, J., Guo, X., Liu, J., and Worsnop, D. R.: "APEC Blue”: Secondary Aerosol Reductions from Emission Controls in Beijing, Sci. Rep., 6, 20668, doi:10.1038/srep20668, 2016.

Surratt, J. D., Lewandowski, M., Offenberg, J. H., Jaoui, M., Kleindienst, T. E., Edney, E. O., and Seinfeld, J. H.: Effect of acidity on secondary organic aerosol formation from isoprene, Environ. Sci. Technol., 41, 5363-5369, 2007.

Surratt, J. D., Chan, A. W., Eddingsaas, N. C., Chan, M., Loza, C. L., Kwan, A. J., Hersey, S. P., Flagan, R. C., Wennberg, P. O., and Seinfeld, J. H.: Reactive intermediates revealed in secondary organic aerosol formation from isoprene, P. Natl. Acad. Sci USA, 107, 6640-6645, 2010.

Tang, G., Zhu, X., Hu, B., Xin, J., Wang, L., Münkel, C., Mao, G., and Wang, Y.: Impact of emission controls on air quality in Beijing during APEC 2014: lidar ceilometer observations, Atmos. Chem. Phys., 15, 12667-12680, doi:10.5194/acp15-12667-2015, 2015.

Tilgner, A. and Herrmann, H.: Radical-driven carbonyl-to-acid conversion and acid degradation in tropospheric aqueous systems studied by CAPRAM, Atmos. Environ., 44, 5415-5422, 2010.

van Donkelaar, A., Martin, R. V., Brauer, M., Kahn, R., Levy, R., Verduzco, C., and Villeneuve, P. J.: Global Estimates of Ambient Fine Particulate Matter Concentrations from Satellite-Based Aerosol Optical Depth: Development and Application, Environ. Health Persp., 118, 847-855, 10.1289/ehp.0901623, 2010.

van Pinxteren, D., Neusüß, C., and Herrmann, H.: On the abundance and source contributions of dicarboxylic acids in sizeresolved aerosol particles at continental sites in central Europe, Atmos. Chem. Phys., 14, 3913-3928, doi:10.5194/acp-14-39132014, 2014.

Wang, G., Niu, S., Liu, C., and Wang, L.: Identification of dicarboxylic acids and aldehydes of PM10 and PM2.5 aerosols in Nanjing, China, Atmos. Environ., 36, 1941-1950, 2002.

Wang, G., Kawamura, K., Lee, S., Ho, K., and Cao, J.: Molecular, seasonal, and spatial distributions of organic aerosols from fourteen Chinese cities, Environ. Sci. Technol., 40, 4619-4625, 2006.

Wang, G., Kawamura, K., Umemoto, N., Xie, M., Hu, S., and Wang, Z.: Water-soluble organic compounds in PM2.5 and sizesegregated aerosols over Mount Tai in North China Plain, J. Geophys. Res., 114, D19208, doi:10.1029/2008jd011390, 2009.

Wang, G., Xie, M., Hu, S., Gao, S., Tachibana, E., and Kawamura, K.: Dicarboxylic acids, metals and isotopic compositions of $\mathrm{C}$ and $\mathrm{N}$ in atmospheric aerosols from inland China: implications for dust and coal burning emission and secondary aerosol forma- 
tion, Atmos. Chem. Phys., 10, 6087-6096, doi:10.5194/acp-106087-2010, 2010.

Wang, G., Kawamura, K., Cheng, C., Li, J., Cao, J., Zhang, R., Zhang, T., Liu, S., and Zhao, Z.: Molecular distribution and stable carbon isotopic composition of dicarboxylic acids, ketocarboxylic acids, and alpha-dicarbonyls in size-resolved atmospheric particles from Xi' an City, China, Environ. Sci. Technol., 46, 4783-4791, doi:10.1021/es204322c, 2012.

Wang, G., Cheng, C., Meng, J., Huang, Y., Li, J., and Ren, Y.: Field observation on secondary organic aerosols during Asian dust storm periods: Formation mechanism of oxalic acid and related compounds on dust surface, Atmos. Environ., 113, 169176, doi:10.1016/j.atmosenv.2015.05.013, 2015.

Wang, G., Wang, J., Ren, Y., and Li, J.: Chemical characterization of organic aerosols from Beijing during the 2014 APEC, Atmos. Res., in preparation, 2016a.

Wang, G., Zhang, R., Gomez, M. E., Yang, L., Levy Zamora, M., Hu, M., Lin, Y., Peng, J., Guo, S., Meng, J., Li, J., Cheng, C., Hu, T., Ren, Y., Wang, Y., Gao, J., Cao, J., An, Z., Zhou, W., Li, G., Wang, J., Tian, P., Marrero-Ortiz, W., Secrest, J., Du, Z., Zheng, J., Shang, D., Zeng, L., Shao, M., Wang, W., Huang, Y., Wang, Y., Zhu, Y., Li, Y., Hu, J., Pan, B., Cai, L., Cheng, Y., Ji, Y., Zhang, F., Rosenfeld, D., Liss, P. S., Duce, R. A., Kolb, C. E., and Molina, M. J.: Persistent sulfate formation from London Fog to Chinese haze, P. Natl. Acad. Sci USA, 113, 13630-13635, doi:10.1073/pnas.1616540113, 2016 b.

Wang, Z., Li, Y., Chen, T., Li, L., Liu, B., Zhang, D., Sun, F., Wei, Q., Jiang, L., and Pan, L.: Changes in atmospheric composition during the 2014 APEC conference in Beijing, J. Geophys. Res.Atmos., 120, 12695-12707, doi:10.1002/2015JD023652, 2015.

Weber, R. J., Guo, H., Russell, A. G., and Nenes, A.: High aerosol acidity despite declining atmospheric sulfate concentrations over the past 15 years, Nat. Geosci., 9, 282-285, doi:10.1038/ngeo2665, 2016.

Wei, X., Gu, X., Chen, H., Cheng, T., Wang, Y., Guo, H., Bao, F., and Xiang, K.: Multi-Scale Observations of Atmosphere Environment and Aerosol Properties over North China during APEC Meeting Periods, Atmosphere, 7, 4, doi:10.3390/atmos7010004, 2016.
Xing, L., Fu, T.-M., Cao, J. J., Lee, S. C., Wang, G. H., Ho, K. F., Cheng, M.-C., You, C.-F., and Wang, T. J.: Seasonal and spatial variability of the $\mathrm{OM} / \mathrm{OC}$ mass ratios and high regional correlation between oxalic acid and zinc in Chinese urban organic aerosols, Atmos. Chem. Phys., 13, 4307-4318, doi:10.5194/acp13-4307-2013, 2013.

Xu, W. Q., Sun, Y. L., Chen, C., Du, W., Han, T. T., Wang, Q. Q., Fu, P. Q., Wang, Z. F., Zhao, X. J., Zhou, L. B., Ji, D. S., Wang, P. C., and Worsnop, D. R.: Aerosol composition, oxidation properties, and sources in Beijing: results from the 2014 Asia-Pacific Economic Cooperation summit study, Atmos. Chem. Phys., 15, 13681-13698, doi:10.5194/acp-15-13681-2015, 2015.

Xue, H., Khalizov, A. F., Wang, L., Zheng, J., and Zhang, R.: Effects of coating of dicarboxylic acids on the mass- mobility relationship of soot particles, Environ. Sci. Technol., 43, 2787-2792, 2009.

Yu, J. Z., Huang, X.-F., Xu, J., and Hu, M.: When Aerosol Sulfate Goes Up, So Does Oxalate? Implication for the Formation Mechanisms of Oxalate, Environ. Sci. Technol., 39, 128-133, doi:10.1021/es049559f, 2005.

Zhang, R., Suh, I., Zhao, J., Zhang, D., Fortner, E. C., Tie, X., Molina, L. T., and Molina, M. J.: Atmospheric new particle formation enhanced by organic acids, Science, 304, 1487-1490, doi:10.1126/science.1095139, 2004.

Zhang, Q., Jimenez, J. L., Worsnop, D. R., and Canagaratna, M.: A case study of urban particle acidity and its influence on secondary organic aerosol, Environ. Sci. Technol., 41, 3213-3219, 2007.

Zhang, R., Khalizov, A., Wang, L., Hu, M., and Xu, W.: Nucleation and growth of nanoparticles in the atmosphere, Chem. Rev., 112, 1957-2011, doi:10.1021/cr2001756, 2012.

Zhang, R., Wang, G., Guo, S., Zamora, M. L., Ying, Q., Lin, Y., Wang, W., Hu, M., and Wang, Y.: Formation of urban fine particulate matter, Chem. Rev., 115, 3803-3855, doi:10.1021/acs.chemrev.5b00067, 2015.

Zhao, J., Khalizov, A., Zhang, R., and McGraw, R.: Hydrogenbonding interaction in molecular complexes and clusters of aerosol nucleation precursors, J. Phys. Chem. A, 113, 680-689, 2009 . 